\title{
STUDENT ENGAGEMENT DAN PARENT INVOLVEMENT SEBAGAI PREDIKTOR PRESTASI BELAJAR MATEMATIKA SISWA SMA YOGYAKARTA
}

\author{
Asmaul Jannah Siregar \\ Mahasiswa program pasca sarjana Fakultas Psikologi Universitas Gadjah Mada \\ princesshadana@ymail.com
}

\begin{abstract}
This research is constituted by a number of problems of education, such as the behavior of the brawl, bullying, behavior ditching, and lack of parental control to the education of children and low learning achievement in mathematics to high school students (high school) in Indonesia, whereas mathematics is one of the subjects to be indicators of success education in a country. The purpose of this study is to predict the mathematics achievement of high school students based on student engagement and parent involvement. This research was conducted with a quantitative approach to the multiple regression analysis. The subjects were high school students in Yogyakarta grade XI numbered 86 people. The data collection is done by using a scale of student engagement and parent involvement, whereas mathematics achievement was taken from the Final Examination Semester (UAS) semester of 2013/2014 academic year. Based on the analysis we concluded that student engagement and parent involvement together can not predict mathematics achievement $(F=0.822 ; p 0.443)$.
\end{abstract}

Keywords: Student Engagement, parent involvement, mathematics achievement

\begin{abstract}
Abstraksi. Penelitian ini didasari oleh banyaknya problematika pendidikan seperti perilaku tawuran, bullying, perilaku membolos, dan kurangnya kontrol orangtua terhadap pendidikan anak dan rendahnya prestasi belajar matematika pada siswa Sekolah Menengah Atas (SMA) di Indonesia, padahal matematika merupakan salah satu mata pelajaran yang menjadi indikator keberhasilan pendidikan di suatu negara. Tujuan penelitian ini yaitu untuk memprediksi prestasi belajar matematika siswa SMA berdasarkan student engagement dan parent involvement. Penelitian ini dilakukan dengan pendekatan kuantitatif dengan analisis regresi berganda. Subjek penelitian adalah siswa SMA kelas XI IPA di Yogyakarta berjumlah 86 orang. Pengumpulan data dilakukan dengan menggunakan skala student engagement dan parent involvement, sedangkan prestasi belajar matematika diambil dari nilai Ujian Akhir Semester (UAS) semester ganjil tahun pelajaran 2013/2014. Berdasarkan hasil analisis data diperoleh kesimpulan bahwa student engagement dan parent involvement secara bersama-sama tidak dapat memprediksi prestasi belajar matematika $(\mathrm{F}=0,822 ; \mathrm{p} 0,443)$.
\end{abstract}

Kata Kunci: Student Engagement, parent involvement, prestasi belajar matematika

\section{PENDAHULUAN}

Matematika merupakan salah satu mata pelajaran yang dijadikan indikator keberhasilan pendidikan di suatu negara. Matematika merupakan mata pelajaran yang sangat penting untuk dipelajari oleh siswa di setiap jenjang pendidikan karena kemanfaatannya dalam kehidupan manusia. Manfaat matematika, antara lain dikemukakan oleh Raphael (tanpa tahun) yang mengatakan bahwa matematika memiliki dua fungsi utama, yakni sebagai ilmu terapan (applied science) dan ilmu murni (pure science). Sebagai ilmu terapan, matematika digunakan dalam kehidupan praktis sehari-hari hampir di semua bidang kehidupan, dan ilmu murni mengandung arti bahwa matematika digunakan untuk meningkatkan ilmu pengetahuan.

Matematika juga memberikan sumbangan 
yang sangat besar terutama di bidang sains dan teknologi, karena matematika merupakan ilmu dasar (basic science) bagi kedua bidang tersebut. Dengan alasan tersebutlah, matematika dikaji dan dipelajari sebagai suatu ilmu dari tingkat sekolah dasar sampai perguruan tinggi.

Belajar matematika akan sangat membantu mengasah kemampuan berlogika secara benar, membantu melatih anak untuk mengembangkan kemampuan memahami bahwa suatu masalah yang komplek tidak lain adalah kumpulan beberapa masalah yang sederhana, serta melatih kemampuan untuk memecahkan masalah yang komplek menjadi beberapa masalah yang sederhana, serta dapat membantu melatih anak untuk mengembangkan kemampuan mencari pemecahan masalah dan membiasakan anak melakukan penilaian masalah secara terukur.

Prestasi belajar siswa Indonesia khususnya di bidang matematika dianggap masih rendah. Hal ini dapat dilihat dari hasil survey yang dilakukan oleh PISA (Programme for International Student Assessment) yang menunjukkan bahwa Indonesia menduduki peringkat ke-64 dari 65 negara yang disurvey pada tahun 2012 dalam skor matematika (OECD, 2012). Berdasarkan data TIMSS (Trends in International Mathematics and Science Study) tahun 2011 yang dilakukan dengan melihat skor rata-rata siswa kelas VIII, Indonesia menduduki peringkat ke-38 dari 42 negara.

Salah satu cara untuk melihat kualitas dan mutu pendidikan di Indonesia yaitu melalui evaluasi yang dilakukan terhadap proses pendidikan yang telah berlangsung, salah satunya yaitu dengan mengadakan ujian terstandarisasi di Indonesia berupa Ujian Nasional (UN). Tahun 2012 siswa SMA yang tidak lulus UN mencapai 7.579 siswa dari 1.524.704 peserta UN. Angka tersebut didapat dari siswa yang nilai akhir rata-ratanya tidak mencapai 5,5 sebanyak 5.300 siswa $(69,4 \%)$. Juga karena ada satu atau lebih mata pelajaran yang nilainya kurang dari 4 (30,06\%). Nilai akhir rata-rata tersebut adalah jumlah nilai UN murni digabungkan dengan nilai sekolah, dengan masing-masing bobot nilai 60:40, berdasarkan data tersebut kebanyakan siswa memiliki nilai yang kurang pada Bahasa Indonesia dan Matematika (Sulistyo, 2012).

Mendikbud memaparkan bahwa persentase kelulusan tahun 2013 ini turun $0,02 \%$ dari tahun sebelumnya yang mencapai 99,5\%, karena tingkat kelulusan tahun 2013 yang hanya mencapai 99,48\% dan persentase ketidaklulusan $0,52 \%$. Jumlah peserta UN SMA/MA tahun ajaran 20122013 adalah 1.581.286 siswa, dan siswa yang dinyatakan lulus UN berjumlah 1.573.036 siswa, sedangkan yang tidak lulus berjumlah 8.250 siswa. Data yang diperoleh dari hasil ujian nasional SMA IPA di provinsi DI Yogyakarta dari 8269 siswa yang mengikuti ujian nasional, 1772 diantaranya tidak lulus yaitu sekitar 21,43\%, dengan rata-rata nilai matematika dan pelajaran pengetahuan alam lain yang masih belum memuaskan.

Studi awal yang dilakukan di sebuah SMA di Yogyakarta menunjukkan bahwa nilai raport Semester Ganjil Tahun ajaran 2013/2014 yang berada di bawah Kriteria Kelulusan Minimal (KKM) pada pelajaran matematika sebanyak 87 dari 309 siswa atau sebesar $28,16 \%$. Nilai KKM pelajaran matematika di sekolah tersebut ialah 76. Ada beberapa faktor yang dapat mempengaruhi prestasi belajar siswa. Secara umum, faktor yang dapat mempengaruhi prestasi belajar siswa dapat dikategorikan menjadi dua, yaitu faktor internal dan eksternal (Suryabrata, 2002).

Peran lingkungan dapat memberikan pengaruh pada prestasi belajar siswa. Hal 
tersebut dapat terlihat dari konsep reciprocal interaction oleh Bandura, yaitu person (diri), environment (lingkungan), dan behavior (perilaku). Peran lingkungan dapat dilihat dari sudut pandang ekologi seperti yang dijelaskan oleh Bronfenbrenner (Santrock, 2010b), bahwa faktor lingkungan dapat mempengaruhi prestasi belajar siswa. Hal ini dapat dipahami dengan melihat tingkatan yang dapat mempengaruhi individu. Interaksi yang terjadi pada mikrosistem meliputi individu dengan keluarga, sekolah, teman sebaya, dan tetangga mampu saling memberikan pengaruh pada performa individu.

Siswa usia remaja identik dengan teman sebaya sebagai faktor lingkungan yang banyak memberikan pengaruh, namun pada konteks pendidikan khususnya terkait dengan keberhasilan siswa di sekolah, yang paling memberikan kontribusi adalah dukungan orang tua dan guru bukan dukungan dari teman (Demaray \& Malecki, 2002; Malecki \& Demaray, 2003; Fezer, 2008). Keterkaitan antara lingkungan sekolah dengan rumah dapat menjadi indikator capaian prestasi siswa di sekolah. Prestasi siswa di sekolah memerlukan hubungan yang positif antara lingkungan sekolah dan rumah (Santrock, 2011). Senada dengan yang diungkapkan Mufarrikhatul (2011), bahwa faktor dukungan orang tua memberikan kontribusi secara langsung pada prestasi akademik siswa sebesar 81,6 \% pada siswa SMA kemudian disusul oleh dukungan sosial yang diterima dari teman sebesar 11,6 \% pada siswa SMA.

Problematika dalam dunia pendidikan saat ini cukup kompleks, dan salah satu problematika yang dihadapi para pendidik saat ini adalah banyaknya perilaku tawuran, bullying di sekolah, perilaku membolos, dan sebagainya. Sekolah tidak lagi menjadi tempat yang menarik dan menyenangkan bagi siswa. Motivasi, keterikatan, dan prestasi pada banyak siswa menurun selama awal masa remaja (Ryan, 2011). Faktor internal individu seperti emosi, motivasi, dan keterikatan siswa pada sekolah diprediksi sebagai penyebab beberapa permasalahan dalam dunia pendidikan (Dharmayana, 2010).

Permasalahan tersebut juga muncul dikarenakan tidak adanya kontrol dari orangtua terhadap pendidikan anak. Orang tua menyerahkan sepenuhnya tanggungjawab pendidikan kepada sekolah. Keluarga merupakan pengalaman pertama bagi anakanak, pendidikan di lingkungan keluarga dapat menjamin kehidupan emosional anak untuk tumbuh dan berkembang. Di lingkungan keluarga akan tumbuh sikap tolong menolong, tenggang rasa sehingga tumbuhlah kehidupan keluarga yang damai dan sejahtera, keluarga berperan dalam meletakkan dasar pendidikan agama dan sosial (Ihsan, 2001).

Siswa yang memiliki keterikatan pada sekolah dalam beberapa penelitian diketahui dapat meningkatkan kesuksesan akademik. Siswa yang masuk sekolah teratur dan tidak pernah bolos, berkonsentrasi pada saat belajar, menegakkan disiplin dan mematuhi peraturan sekolah, serta menghindari perilaku buruk secara umum memiliki peringkat dan performansi yang lebih baik pada ujian (Bandura, Barbanelli, Caprar, \& Pastorelli, 1996; Caraway, Tucker, Reinke, \& Hall, 2003; Finn \& Rock, 1997). Di sekolah di mana siswa merasa peduli dan didukung serta diberi kepercayaan bahwa mereka dapat berhasil, dan di mana keberhasilan akademis merupakan tujuan penting, siswa memiliki tingkat prestasi akademik yang lebih tinggi (Yair, 2000).

Keterlibatan orangtua (parent involvement) dapat meningkatkan prestasi matematika, keterlibatan tersebut dapat berupa dorongan yang diberikan orangtua, seperti membantu anak dalam pembelajaran 
matematika, mendampingi anak ketika mengerjakan pekerjaan rumah, membantu anak memberikan pemahaman pada permasalahan matematika yang sukar (Cai, 2003; Cao, Bishop, \& Forgasz, 2006)

Penelitian Yan danLin(2005) menjelaskan bahwa parent involvement sebagai bentuk dari social capital secara umum merupakan sebuah prediktor penting dalam menjelaskan prestasi matematika siswa Kaukasian, dimana social capital tersebut dibangun dari kekuatan hubungan antara orang dewasa dan anak (Coleman, 1997).

Penelitian yang dilakukan Epstein mengenai parent involvement kebanyakan pada siswa usia sekolah dasar dan masih sedikit yang melihat pengaruh parent involvement dalam dunia pendidikan pada siswa usia sekolah menengah atas. Anderman dan Maehr (1994) dan Lepper, Sethi, Dialdin, dan Drake (1997) menyatakan bahwa terjadi perubahan dalam cara siswa memberi reaksi terhadap sekolah dan kegiatan belajar agar menjadi siswa yang sukses, dan terjadi penurunan motivasi siswa dalam mengerjakan tugas sekolah. Perubahan alami yang dialami siswa dari masa kecil ke masa remaja dan pencarian mereka akan kemandirian mempengaruhi perubahan keterlibatan orangtua dalam pendidikan. Mengetahui dan mempertimbangkan hal ini menjadi alasan penting untuk mengetahui hubungan antara parent involvement dan prestasi belajar siswa, sikap mereka terhadap sekolah, dan motivasi mereka dalam belajar.

Epstein (1992) dalam rangkuman penelitiannya mengenai parent involvement menyatakan bahwa siswa yang sukses akademik, memiliki aspirasi yang tinggi dan perilaku postif lainnya jika mereka memiliki orangtua yang sadar, berpengetahuan luas, mendukung, dan terlibat.

Berdasarkan beberapa uraian di atas, dapat dilihat bahwa student engagement (keterikatan siswa) dan parent involvement (keterlibatan orangtua) menjadi prediktor bagi prestasi belajar, khususnya prestasi belajar matematika siswa. Hipotesis dari penelitian ini adalah Student Engagement dan Parent Involvement dapat memprediksi prestasi matematika siswa.

\section{METODE PENELITIAN}

Penelitian ini menggunakan tiga variabel, dua variabel sebagai prediktor (student engagement dan parent involvement) dan satu variabel kriterium (prestasi belajar matematika). Desain penelitian yang digunakan dalam penelitian ini adalah pendekatan kuantitatif dengan teknik analisis regresi berganda.

Subjek penelitian adalah siswa kelas XI IPA SMA X Yogyakarta. Kelas XI IPA di SMA X Yogyakarta sebanyak lima kelas dan diambil tiga kelas sebagai subjek penelitian yang berjumlah 86 orang siswa. Adapun karakteristik subjek penelitian ini adalah remaja berusia 16 tahun hingga 18 tahun, berjenis kelamin laki-laki maupun perempuan, siswa kelas dan diampu oleh guru matematika yang sama.

Alat Pengkuran Data dalam penelitian ini adalah dengan melihat Prestasi belajar matematika siswa, yaitu hasil belajar matematika yang diperoleh siswa dalam jangka waktu tertentu. Prestasi belajar matematika dapat dinyatakan dalam nilai rapor atau nilai tes matematika. Data diperoleh dari dokumen hasil nilai ujian akhir semester (UAS) siswa kelas XI IPA semester ganjil tahun pelajaran 2013/2014. Nilai yang digunakan adalah nilai total dari soal pilihan berganda dan esai.

Skala Student Engagement dalam penelitian ini dapat dilihat dari keterikatan perilaku, kognitif, dan emosional siswa terhadap sekolah. Skala untuk mengukur 
Student Engagement disusun berdasarkan konstruk yang dikembangkan oleh Fredricks, Blumenfeld, Friedel, \& Paris (2004) yang terdiri dari tiga aspek yaitu behavioral (perilaku), cognitive (kognitif), dan emotional (emosional). Skala ini memiliki koefisien reliabilitas alpha sebesar $\alpha=0,862$.

Skala Parent Involvement dalam penelitian ini adalah penilaian dan persepsi siswa terhadap keterlibatan orangtua secara langsung terhadap proses pendidikan dan pembelajaran siswa, dalam penelitian ini khususnya Prestasi belajar matematika. Instrumen yang digunakan dalam penelitian ini disusun berdasarkan instrumen survey dari United States Department of Educational Longitudinal Study of 2002. Instrumen ini disusun berdasarkan klasifikasi enam aspek dari Parent Involvement yaitu Parent Involvement yaitu Parenting, Communicating, Volunteering, Learning at home, Decision Making, dan Collaborating with community.
Skala ini memiliki koefisien reliabilitas alpha sebesar $\alpha=0,887$

\section{HASIL DAN PEMBAHASAN}

Dalam penelitian ini diambil 3 kelas dari 5 kelas XI IPA yang ada di kelas XI IPA di SMA X Yogyakarta.

Tabel 1

Deskripsi Subjek Penelitian

\begin{tabular}{lccc}
\hline Kelas & $\begin{array}{c}\text { Jumlah } \\
\text { Siswa }\end{array}$ & $\begin{array}{c}\text { Jumlah } \\
\text { Siswa } \\
\text { Laki-laki }\end{array}$ & $\begin{array}{c}\text { Jumlah } \\
\text { Siswa } \\
\text { Perempuan }\end{array}$ \\
\hline XI IPA 2 & 29 & 12 & 17 \\
XI IPA 4 & 29 & 12 & 17 \\
XI IPA 5 & 28 & 10 & 18 \\
Total & 86 & 34 & 52 \\
\hline
\end{tabular}

Adapun karakteristik subjek berupa skor maksimum, skor minimum, mean, dan deviasi standar dalam statistik data empirik dan statistik data hipotetik.

Tabel 2

Deskripsi Empirik dan Hipotetik Data Penelitian

\begin{tabular}{|c|c|c|c|c|c|c|c|c|}
\hline \multirow{2}{*}{ Variabel } & \multicolumn{4}{|c|}{ Hipotetik } & \multicolumn{4}{|c|}{ Empirik } \\
\hline & Min & Max & Mean & SD & Min & Max & Mean & SD \\
\hline Student Engagement & 22 & 88 & 55 & 11 & 33 & 85 & 64,38 & 7,66 \\
\hline Parent Involvement & 25 & 100 & 62,5 & 12,5 & 51 & 95 & 72,24 & 8,13 \\
\hline $\begin{array}{l}\text { Prestasi Belajar } \\
\text { Matematika }\end{array}$ & 0 & 100 & 50 & 16,6 & 25 & 81 & 59,01 & 13,04 \\
\hline
\end{tabular}

Uji linieritas hubungan digunakan untuk mengetahui linieritas hubungan antara variabel prediktor dengan variabel kriterium. Adapun hasil uji linieritas dalam penelitian ini terangkum dalam tabel 3 berikut ini:

Tabel 4.4

Hasil Uji Linearitas

\begin{tabular}{cccc}
\hline Prediktor & $\mathbf{F}_{\text {deviasi }}$ & $\mathbf{p}$ & Status \\
\hline Student Engagement & 0,990 & 0,495 & Linier \\
Parent Involvement & 1,085 & 0,388 & Linier \\
\hline
\end{tabular}

Kriterium: Prestasi Matematika
Hipotesis dalam penelitian ini adalah bahwa Student Engagement dan Parent Involvement dapat memprediksi prestasi matematika siswa SMA. Koefisien korelasi $\mathrm{R}=0,139$ dan nilai $\mathrm{F}=0,822$ dengan nilai $\mathrm{p}=0,443(\mathrm{p}>0,05)$.

Berdasarkan hasil analisis tersebut, dapat disimpulkan bahwa tidak terdapat hubungan antara student engagement dan parent involvement dengan prestasi belajar matematika pada siswa SMA $(\mathrm{F}=0,822$; 
$\mathrm{p}=0,443)$. Hipotesis penelitian yang diajukan ditolak, bahwa student engagement dan parent involvement sebagai prediktor tidak dapat memprediksi prestasi belajar Matematika pada siswa SMA.

Penelitian ini dimaksudkan untuk menguji secara empirik prediksi student engagement dan parent involvement terhadap prestasi matematika pada siswa SMA. Berdasarkan hasil analisis yang diperoleh menunjukkan tidak adanya hubungan yang signifikan antara student engagement dan parent involvement dengan prestasi matematika siswa SMA. Hasil tersebut diperoleh dari nilai $\mathrm{R}=0,139$ dan nilai $p=0,443(p>0,05)$. Dengan demikian dapat dikatakan bahwa student engagement dan parent involvement secara bersama-sama tidak dapat memprediksi prestasi matematika siswa SMA.

Hasil penelitian menunjukkan bahwa student engagement tidak dapat memprediksi prestasi matematika siswa SMA. Hasil penelitian ini berbeda dengan hasil-hasil penelitian sebelumnya (Singh, dkk, 2002; Dotterer \& Lowe, 2010; Bryan, dkk, 2012) yang menyatakan bahwa student engagement merupakan prediktor yang signifikan terhadap prestasi matematika siswa.

Pada penelitian Fredricks, dkk (2004) disimpulkan bahwa ada bukti yang menunjukkan hubungan antara keterikatan perilaku dengan prestasi, namun kemungkinan ada faktor mediator yang mempengaruhi hubungan ini. Peran keterikatan perilaku tidak secara jelas memprediksi pemahaman yang dalam materi pelajaran. Temuan lain dari penelitian Fredricks, dkk menunjukkan adanyahubunganantara keterikatan emosional dengan prestasi walaupun dianggap kecil pengaruhnya, sedangkan hubungan antara keterikatan kognitif dan prestasi lebih besar, sebab tes prestasi disusun untuk mengukur pemahaman yang lebih dalam terhadap materi pelajaran.

Pada umumnya siswa akan lebih terikat dengan sekolah jika mereka mendapat dukungan dari orang dewasa di sekolah, merasa tertantang dengan tugas-tugas yang menarik, struktur sekolah yang cukup memadai, memperoleh dukungan untuk lebih mandiri, kesempatan belajar dengan teman sebaya, dan kesempatan untuk dapat belajar dan mengikuti kegiatan sekolah secara aktif. Hal-hal ini yang dapat meningkatkan student engagement.

Fredriks \& Eccles (2002) menyatakan bahwa bagi sebagian siswa, keterikatan mereka pada sekolah menurun ketika memasuki masa remaja. Hal ini disebabkan karena pada masa remaja, remaja lebih fokus pada karir, pacaran, dan eksplorasi identitas diri (Santrock, 2003).

Para peneliti telah menyatakan bahwa prestasi matematika pada siswa SMA adalah sebuah fungsi dari beberapa variabel yang saling berhubungan, diantaranya kemampuan siswa, inteligensi, sikap dan persepsi, motivasi, faktor sosial ekonomi, orangtua dan teman sebaya, hubungan dengan sekolah, dan lainnya. Penelitian sebelumnya juga menyatakan bahwa pengalaman siswa dalam kelas matematika berhubungan dengan interest (minat) dan minat adalah prediktor prestasi matematika yang sangat signifikan.

Variabel yang berkaitan dengan kemampuan siswa juga merupakan prediktor yang sangat penting terhadap tinggi rendahnya prestasi matematika. Faktor inteligensi misalnya sebagai faktor internal yang ada pada diri siswa dalam belajar sedangkan dukungan atau keterlibatan orangtua merupakan faktor eksternal.

Pada penelitian Alsa (2013) mengenai model yang efektif dari dimensi-dimensi 
school wellbeing untuk memprediksi prestasi matematika siswa SMA juga menunjukkan bahwa dari lima variabel prediktor (efikasi diri, hubungan guru- siswa, student engagement, dukungan orangtua, dan iklim sekolah) hanya dua prediktor yang menjadi prediktor kuat yang dapat memprediksi prestasi matematika, yaitu efikasi diri dan hubungan guru-siswa. Sedangkan tiga prediktor lainnya walaupun memiliki korelasi dengan prestasi belajar matematika ternyata tidak dapat meningkatkan daya prediksi model.

Parent involvement dalam penelitian ini juga tidak bisa memprediksi prestasi matematika siswa SMA. Hasil penelitian ini berbedadengan hasilpenelitian terdahuluyang menyatakan bahwa adanya pengaruh positif yang signifikan parent involvement terhadap prestasi matematika siswa (Yan \& Lin, 2005; Cai, 2003; Hong, dkk, 2010). Keterlibatan dan dukungan orangtua merupakan dukungan yang paling penting bagi kehidupan anak, namun bukan merupakan dukungan yang mampu membantu siswa dalam mencapai kesuksesan akademik (Fezer, 2008).

Banyak hal yang dapat menjelaskan mengapa parent involvement tidak dapat memprediksi prestasi matematika siswa SMA. Karakteristik siswa SMA yang berada pada masa remaja menjadi salah satu alasan terjadinya perbedaan hasil penelitian, karena masa remaja merupakan masa yang sangat kompleks dimana perkembangan fisik, emosional, dan intelektual berkembang dengan pesat. Pada masa ini juga muncul pertanyaan mengenai identitas diri, adanya ekspektasi dari teman sebaya, dan adanya nilai normatif yang mempengaruhi (Fenwick, 1987).

Stevenson \& Baker (1987) menjelaskan bahwa keterlibatan orangtua menjadi berkurang baik itu di rumah maupun di sekolah seiring dengan perkembangan anak menjadi dewasa. Beberapa orangtua percaya bahwa keterlibatan mereka dalam pendidikan anaknya menjadi tidak sepenting ketika anak duduk di bangku sekolah dasar.

Dalam laporan akhir sebuah proyek mengenai instrumen parent involvement di Carolina utara dinyatakan orangtua juga beranggapan bahwa anak remaja memiliki hasrat dan keinginan untuk lebih mandiri sehingga para orangtua mengurangi tingkat keterlibatan mereka (Eccles \& Harold, 1993; Hickman, et.al, 1995; Prosise, 1990; Simon, 2000). Parent involvement mungkin juga berkurang ketika seorang anak naik ke tingkat sekolah yang lebih tinggi dikarenakan orangtua mungkin tidak lagi menguasai beberapa materi pelajaran pada tingkat tersebut (Eccles \& Harold, 1993).

Spera (2005) mengungkapkan adanya kebutuhan dari remaja untuk mengekspresikan otonomi, sehingga remaja akan merespon negatif keterlibatan orangtua yang tinggi. Menurut Woolfolk (2007), keterlibatan orangtua dalam pendidikan hanya mempunyai peranan yang sangat kecil dalam menentukan keberhasilan siswa, faktor yang lebih besar adalah ada pada diri siswa.

Penelitian Duschene dan Ratelle (2010) menunjukkan bahwa perilaku orangtua dapat membuat siswa pada masa transisi bertambah cemas dan menjadi depresi, yaitu ketika orangtua tidak mampu membangun kedekatan emosional dengan siswa. Kesulitan orangtua untuk menyesuaikan diri dengan remaja disebabkan siswa di usia awal remaja, cenderung berpikir perasaan mereka unik dan orang-orang di sekelilingnya (orangtua dan guru) tidak pernah merasakan emosi seperti yang mereka rasakan (Ormrod, 2006).

Pada siswa usia remaja, karakteristik dukungan dan keterlibatan yang diberikan dari orangtua ialah dukungan yang mampu memberikan individu otonomi dan orientasi 
pada prestasi. Orangtua diharapkan dapat menjelaskan alasan secara konsisten dan rasional terhadap aturan yang diberlakukan pada siswa usia remaja melalui proses diskusi. Hal ini juga dapat dilakukan dalam pengambilan keputusan terhadap isu-isu yang melibatkan diri remaja seperti pilihan-pilihan karir masa depan dan lainnya (Shaffer \& Kipp, 2010).

Selain hal yang telah disebutkan di atas, finansial dan jaringan (social network) yang dimiliki oleh orangtua juga menjadi alasan tidak efektifnya keterlibatan orangtua. Sheldon (2002) menyatakan bahwa jika orangtua memiliki jaringan sosial yang sedikit, maka akan berkurang pula keterlibatan mereka pada pendidikan anaknya. Sebagai tambahan, Sheldon juga menyatakan bahwa orangtua dengan kondisi finansial yang cukup dapat lebih membuat orangtua terlibat dan konsentrasi dalam mendukung pendidikan anak. Beragamnya latar belakang sosial ekonomi orangtua juga mampu memberikan pengaruh pada dukungan dan keterlibatan yang diberikan kepada anaknya. Hasil studi oleh Fan (2012) menyatakan bahwa adanya pengaruh positif pada latar belakang sosial ekonomi orangtua terhadap performa prestasi belajar siswa. Namun dalam penelitian ini faktor demografi orangtua tidak dibatasi.

Namun demikian, di Indonesia sendiri, akses untuk terlibatnya orangtua di sekolah belum difasilitasi dengan maksimal. Tidak semua orangtua tergabung dalam komite sekolah, dan tidak banyak pula kegiatan sekolah yang melibatkan orangtua. Dalam wawancara yang dilakukan oleh penulis, komunikasi antara sekolah dan rumah juga sangat sedikit. Home visit dilakukan ketika siswa tidak masuk kelas melebihi batas yang ditetapkan. Demikian juga hal nya dengan pemanggilan orangtua ke sekolah, kebanyakan adalah ketika anak mendapat masalah di sekolah. Penjelasan lainnya adalah adanya strategi reaktif, orangtua hanya akan memberikan dukungan dan terlibat pada pendidikan anak ketika mengetahui anaknya mendapatkan prestasi yang rendah (Chen, 2005).

Hal senada dijelaskan oleh Kiamanesh (2004) dan Chen (2005) bahwa prestasi belajar Matematika siswa dapat dipengaruhi oleh latar belakang keluarga seperti pendidikan dan dukungan instrumental di rumah. Siegler, et al. (2012) menyebutkan latar belakang pendidikan dan pendapatan orangtua mampu mempengaruhi prestasi belajar Matematika siswa. Latar belakang pendidikan dan pendapatan orangtua mampu mempengaruhi prestasi belajar Matematika siswa (Siegler,dkk, 2012).

Dari beberapa penelitian tentang prestasi matematika juga diperoleh bahwa faktor internal siswa sangat mempengaruhi seperti inteligensi. Hasil penelitian Kusumaningrum (2014) menyatakan bahwa dukungan orangtua, dukungan guru, dan inteligensi dapat memprediksi prestasi belajar matematika. Namun, dari ketiga variabel tersebut dukungan orangtua saja tidak dapat memprediksi prestasi belajar matematika.

Penelitian ini memiliki keterbatasan dalam jumlah sampel yang masih terbatas dan hanya diambil dari satu sekolah sehingga mungkin belum mewakili populasi yang ada. Demikian juga dengan alat ukur dalam penelitian ini masih terlalu umum dan tidak spesifik membahas mengenai prestasi matematika, namun proses dalam pembuatan skala sudah melalui prosedur dan standar yang telah ditetapkan.

Keterbatasan lain dari penelitian ini adalah skala diisi oleh siswa. Oleh karena semua informasi mengenai hubungan parent involvement dan prestasi belajar matematika siswa adalah dari perspektif siswa. Bisa 
terjadi bias dalam perspektif siswa yang memungkinkan terjadinya pengaruh pada hasil uji hipotesis yang dilakukan.

\section{SIMPULAN}

Berdasarkan analisis dan pembahasan sebelumnya, dapat disimpulkan bahwa student engagement dan parent involvement tidak dapat memprediksi prestasi Matematika pada siswa SMA. Student engagement menurun ketika memasuki masa remaja pada sebagian siswa. Hubungan antara cognitive engagement dengan prestasi matematika lebih besar sebab tes prestasi disusun untuk mengukur pemahaman yang lebih dalam terhadap materi pelajaran.

Beberapa alasan mengapa parent involvement tidak dapat memprediksi prestasi matematika karena remaja lebih mandiri daripada siswa pada masa sebelumnya, orangtua merasa bahwa keterlibatan mereka tidak begitu penting seiring dengan naiknya anak ke tingkat pendidikan yang lebih tinggi, orangtua tidak menguasai materi pelajaran pada tingkat tersebut khususnya matematika, dan adanya faktor finansial serta social network.

Berdasarkan hasil penelitian dan kesimpulan, saran yang diberikan kepada orang tua yaitu perlu mengevaluasi bentuk keterlibatan yang diberikan pada siswa usia remaja. Bagi peneliti selanjutnya yang tertarik atas penelitian yang berkaitan dengan matematika, student engagement, parent involvement hendaknya menambah data persepsi tentang variabel yang diteliti tidak hanya dari perspektif siswa namun juga dari orangtua dan guru.

\section{DAFTAR PUSTAKA}

Alsa, A. (2005). Program belajar, jenis kelamin, belajar berdasar regulasi diri dan prestasi belajar matematika pada pelajar SMA negeri di Yogyakarta. Disertasi (tidak diterbitkan). Yogyakarta: Fakultas Psikologi Universitas Gadjah Mada.

Bandura, A., Barbaranelli, C., Caprara, G. V., \& Pastorelii, C. (1996). Multifaceted impact of self efficacy beliefs on academic learning. Child Development, 67, 1206-122

BSNP (2006). Standar kompetensi dan kompetensi dasar pelajaran matematika SMA.

Bryan, J., Moore-Thomas, C., Gaenzle, S., Kim, J., Lin, C., \& Na, G. (2012). The effects of school bonding on high school seniors' academic achievement. Journal of Counseling \& Development, 90, 467-480

Cai, J. (2003). Investigating parental roles in students' learning in mathematics from a crossnational perspective. Mathematics Education Research Journal . 15 (2), 87-106

Cao, Z., Bishop, A., \& Forgasz, H. (2006). Perceived parental influence on mathematics learning: A comparison among students in China and Australia. Educational Studies in Mathematics, 64, 85-106

Chen, W., \& Gregory, A. (2010). Parental Involvement as a protective factor during the transition to high school. The Journal of Educational Research, 103, 53-62.

Demaray, M. K., \& Malecki, C. K. (2002). The relationship between perceived social support and maladjustment for student at risk. Psychology in the School, 39, 305-316. 
Demaray, M. K., Malecki, C. K., Davidson, L. M., Hodgson, K. K., \& Rebus, P. J. (2005). The relationship between social support and student adjustment: A longitudinal analysis. Psychology in the School, 42 (7). doi: 10.1002/pits.20120.

Dharmayana, I. W. (2010). Peran kompetensi emosi dan keterikatan pada sekolah terhadap prestasi akademik siswa unggul di SMA Negeri Yogyakarta. Disertasi (tidak diterbitkan). Yogyakarta: Fakultas Psikologi UGM

Dotterer, A.M., Lowe, K. (2010). Classroom Context, School Engagement, and Academic Achievement in Early Adolescence. $J$ Youth Adolescence, 40, 1649-1660

Eccles, J. S., \& Harold, R. D. (1993). Parent-school involvement during the early adolescent years. Teachers College Record, 94, 568-587

Epstein, J. L. (2001). School, family and community partnerships. Boulder, CO: Westview Press

Epstein, J. L (2008). Improving Family and Community Involvement in secondary school. The Education Digest, 8, 9-12

Epstein, J. L, \& Jansorn, N. R. (2004). School, Family, and Community Partnership link the plan. The Education Digest, 83, 19-23

Epstein, J. L. (2005). School/Family/Community Partnerships. Phi Delta Kappan, 76, 701712

Fenwick, J.J (1987). Middle shoolers: Meeting the social needs. Principal, 66, 43-46

Fezer, M. (2008). Adolescent social network: Student academic success it relates to source and type of support received. Dissertation. USA: ProQuest LLC.

Finn, J. D., \& Rock, D. A. (1997). Academic success among students at risk for school failure. Journal of Applied Psychology, 82, 221-234

Fredricks, J. A., Blumenfeld, P.C., \& Paris, A.H. (2004). School Engagement: Potential of the Concept, State of the Evidence. Review of Educational Psychology. 95 (1) 148-162

Fredricks, J. A., Blumenfeld, P.C., Friedel, J., \& Paris, A.H. (2005). School Engagement. In K.A. Moore \& L. Lippman (Eds.) What do children need to flourish? : Conceptualizing and measuring indicators of positive development. New York, NY : Springer Sciences and Business Media

Hong, S., Yoo, S., You, S., \& Wu, C. (2010). The reciprocal relationship between parental involvement and mathematics achievemet: Autoregressive cross-lagged modelling. The journal of Experimental Education, 78, 419-439

Hong, S., \& Hsiu-Zu, H. (2005). Direct and indirect longitudinal effects of parental involvement on student achievement: Second-order latent growth modelling across ethnic groups. Journal of Educational Psychology, 97 (1), 32-42

Hornby, G. (2011). Parental Involvement in Childhood Education: Building Effective SchoolFamily Partnesrships. New York, NY : Springer Sciences and Business Media 
http://studyl-solo.com/archives/435. Alasan Belajar Matematika itu Penting. Diakses pada 17 Desember 2013

http://www.antaranews.com/berita/376294/mendikbud-umumkan-hasil-akhir-un-sma-2013, diakses pada 28 Maret 2014

http://nasional.sindonews.com/read/2013/11/11/15/804091/pembelajaran-matematika-diindonesia-masuk-peringkat-rendah, diakses pada 28 Maret 2014

Hughes, J. \& Kwok, O. M. (2007). Influence of Student-Teacher and Parent-Teacher Relationship on Lower Achieving Readers' Engagement and Achievement in The Primary Grade. Journal of Educational Study. 99 (1) 39-51

Hughes, J. N., Lou, W., Kwok, O. M. \& Loyd, L.K. (2008). Teacher-Student support, effortful Engagement, and Achievement : A 3 year longitudinal study. Journal of Educational Study. 100 (1) 1-14

Ihsan, Fuad, 2001, Dasar-dasar kependidikan, (Jakarta: Rineka Cipta)

Jackson, W.A. (2011). The relationship between parent involvement and student achievement in a Rural Florida High School. Dissertation. Northcentral University

Jacobsen, W. C. (2011). Parental Involvement and academic achievement among children of immigrants. Thesis. Department of Sociology, Brigham Young University.

Klausmeir, H. J. \& Goodwin, W. (1971). Learning and Human Ability Educational Psychology. New York: Horper \& Row Publisher.

Lippman, L., Rivers, A. (2008). Assesing School Engagement: A Guide for Out-Of-School Time Program Paractitioner. Brief Research to Results Trends Child

Masrun \& Martaniah, S. M. (1984). Psikologi Pendidikan. Yogyakarta: Yayasan Penerbitan Fakultas Psikologi Universitas Gadjah Mada.

Morse, A. B., Christenson, S. L., \& Lehr, C. A. (2004). School completion and student engagement: information and strategies for parents. Helping Children at Hime and School II: Handouts for Families and Educators. Minnesota: University of Minnesota.

Mufarrikhatul, U. (2011). Pengaruh dukungan orangtua terhadap prestasi akademik mata pelajaran Ekonomi siswa kelas XI IPS SMA Assa'adah Bungah Gresik Tahun Ajaran 2010/2011. Tesis (tidak diterbitkan). Malang: Fakultas Tarbiyah Universitas Islam Negeri Maulana Malik Ibrahim.

Muller, C. (1998). Gender differences in parental involvement and adolescents' mathematics achievement. Sociology of Education, 71, 336-356

Nuryoto, S. \& Indati, A. (1993). Faktor-faktor yang Mempengaruhi Prestasi Belajar. Laporan Penelitian. Yogyakarta: Fakultas Psikologi Universitas Gadjah Mada.

OECD, 2012. Diakses pada http://www.oecd.org/pisa/keyfindings/pisa-2012-resultsoverview.pdf

Ormrod, J. E. (2006). Educational psychology: Developing learners (5 $5^{\text {th }}$ ed). New Jersey: 
Pearson Merril Prentice Hall

Pallant, J. (2007). SPSS Survival manual: a step by step guide to data analysis using SPSS for windows. New York: McGraw-Hill Open University Press.

Purwodarminto. (1990). Kamus Besar Bahasa Indonesia. Jakarta: Gramedia Pustaka Umum.

Raphael. (Tanpa tahun). Mathematics. http://www.wikimediafoundation.org

Rice, F. P., \& Dolgin, K.G. (2008). The adolescent: Development, relationships and culture $\left(12^{\text {th }} \mathrm{ed}\right)$. United States of America: Pearson Eeduation Inc. Allyn and Bacon

Ryan, A. M. (2011). Peer relationship and academic adjustment during early adolescence. Journal of Early Adolescence, 31, 1, 5-12, DOI: 10.1177/0272431610387605

Ryan, A. M \& Patrick, H. (2001). The classroom social environtment and changes in adolescents' motivation and engagement during middle school. American Educational Research Journal, 38, 437-460

Santrock, J. W. (2010b). Life-span development (13nd ed). New York: Mcgraw-Hill.

Schunk, D.H. (2011). Learning theories an educational perspective. New Jersey, Pearson Prentice Hall.

Sharan, S. Shachar, H. And Levine, T. (1999). The Innovative School: organization and instruction. Greenwood: Praeger

Sheldon, S. B. (2002). Parents' social networks and beliefs as predictors of parent involvement. Elementary School Journal, 102, 301-306

Singh, K., Garnville, M., \& Dika, S. (2002). Mathematics and Science Achievement Effects of Motivation, Interest, and Academic Engagement. The journal of Educational Research, 95(6), 323-332

Spera, C. (2005). A review of the relationship among parenting practices, parenting styles, and adolscent school achievement. Educational Psychology Review, 17(2), 125-146. DOI: $10.100 / \mathrm{s} 10648-005-3950-1$

Stevenson, D. L., \& Baker, D. P. (1987). The family-school relation and the child's school performance. Child Development, 58, 1348-1357

Sudarnoto. Neneng, L.F. (1996). Peranan Motivasi Berprestasi, Keterikatan terhadap Tugas, Persepsi terhadap Matematika dan Kemampuan Berpikir Logis dalam Memprediksi Penguasaan Matematika Siswa SMU (Studi di Lima SMU Katolik KAJ). Research Report. https://lib.atmajaya.ac.id/default.aspx?tabID $=61 \& s r c=k \& i d=40213$

Sulistyo, H. S. (2012). Hasil UN 2012, harian Jogja.Com. diunduh pada tanggal 1 September, 2012.

Suryabrata, S. (2002). Psikologi Pendidikan. Jakarta: Grafindo Persada.

Woolfolk, A. (2007). Educational psychology (10th ed). Boston: Pearson Education.

Woolfolk, A. (2009b). Educational psychology, active learning edition, 10th edition 
(terjemahan, bagian kedua). Yogyakarta: Pustaka Pelajar

Yan, W., Lin, Q. (2005). Parent involvement and mathematics achievement : contrast across racial and ethnic groups. The journal of Educational Research, 99(2), 116-127

Yair, G. (2000). Reforming motivation: How the structure of instruction affects student's learning experiences. British Educational Journal. 26 (2): 191-210

Yair, G. (2003). Desicive moments and key experiences expanding paradigmatic boundaries in the study of school effects, in: C. A. Torres \& A. Antikainen (Eds.). The international handbook on te sociology of education: an international assessment of new research and theory (Lanham, MD, Rowman, \& Littlefield), 124-142 